\title{
ФОРМУВАННЯ ФОТОСИНТЕТИЧНОЇ ПРОДУКТИВНОСТІ COРТІВ ЯЧМЕНЮ ОЗИМОГО (HORDEUM VULGARE L.) ЗАЛЕЖНО ВІД СТРОКІВ СІВБИ ТА РЕГУЛЯТОРІВ РОСТУ В УМОВАХ ЗРОШЕННЯ
}

Заєць С. О., Кисіль Л. Б.

\section{ВСТУП}

Проблема підвищення продуктивності ячменю озимого (Hordeum vulgare L.) залишається однією з основних. Проте останніми роками на Півдні України спостерігаємо складні погодні умови, що супроводжуються значним підвищенням температури повітря, а це призводить до втрат урожаю зерна та спаду рівня виробництва. Тому ячмінь озимий $(H$. vulgare L.) усе частіше у цій зоні висівають на зрошуваних землях, щоб стабілізувати його виробництво ${ }^{1}$.

Окрім зрошення, його врожай залежить від багатьох інших чинників, серед яких найважливішими $є$ біологічні властивості сортів та сукупність технологічних заходів вирощування, а також від особливостей погодних умов і клімату.

Важливим питанням, що визначає можливості максимального накопичення рослинами органічної речовини (до 90-95\% сухої маси врожаю), є процес фотосинтезу, якому належить провідна роль серед чинників, що визначають продуктивність ${ }^{2,3}$.

Тобто врожайність сільськогосподарських культур напряму залежить від площі листя та продуктивності фотосинтезу, і більшою вона може бути за умови, якщо площа листкової поверхні рослин буде оптимальною.

Як і в інших зернових культурах, в ячменю озимого (H. vulgare L.) спостерігаються значні коливання величини сформованої асиміляційної поверхні, що залежить від біологічних особливостей сорту, строків сівби, застосування регуляторів росту та інших елементів технології вирощування, а також агрометеорологічних умов року ${ }^{4,5}$.

\footnotetext{
1 Системи землеробства на зрошуваних землях України / Р.А. Вожегова та ін. Київ : Аграрна наука, 2014. $360 \mathrm{c}$.

2 Ничипорович А.А. Некоторые принципы комплексной оптимизации фотосинтетической деятельности и продуктивность растений. Важнейшие проблемы фотосинтеза в растениеводстве. Москва : АН СССР, 1970. С. 6-22.

${ }^{3}$ Чириков Ю.Г. Фотосинтез: два века спустя. Москва : Знание, 1981. 192 с.

4 Заєць С.О., Онуфран Л.І. Ячмінь ярий на Півдні України : монографія. Херсон : ОЛДІ-ПЛЮС, 2019. 164 c. ISBN 978-966-289-312-0.

${ }^{5}$ Нетіс I.T. Пшениця озима на півдні України : монографія. Херсон :ОЛДІ-ПЛЮС, 2011. 460 с. ISBN 978-966-2393-22-4.
} 
Одним із чинників, що позитивно впливають на формування листкового апарату рослин, $є$ застосування регуляторів росту ${ }^{6}$. Регулятори росту рослин разом із новими сортами та оптимальним строком сівби розглядаються як екологічно безпечні та економічно доцільні засоби підвищення продуктивності с.-г. культур, у тому числі ячменю озимого (H. vulgare L.).

За рахунок їх дії інтенсивніше відбувається формування листкової поверхні, активізуються основні процеси фотосинтезу, поліпшуються умови росту i розвитку рослин та посилюється стійкість до фітопатогенів, що в результаті збільшує на 20-30\% урожай культури та дає змогу отримувати продукцію значно вищої якості $7,8,9,10$.

Тому в умовах нинішнього ведення сільського господарства біостимулятори росту стають невід'ємним елементом інтенсивних технологій ${ }^{11,12}$.

Нині в Україні зареєстровано понад 130 препаратів із регуляторною дією на рослини ${ }^{13}$. Слід відзначити, що нові регулятори росту вітчизняного виробництва за своєю ефективністю не поступаються кращим світовим препаратам, а за такими показниками, як технологічність і вартість, мають значні переваги ${ }^{14}$.

Однак в умовах зрошення Півдня України питання щодо впливу регуляторів росту рослин на фотосинтетичну продуктивність та врожайність сортів ячменю озимого (H. vulgare L.) за різних строків сівби залишається недостатньо вивченим, тому $\epsilon$ важливим й актуальним.

Дуже актуальним є дослідження 3 установлення впливу регуляторів росту Гуміфілд, МИР i PROLIS на формування площі листкової поверхні, фотосинтетичного потенціалу i чистої продуктивності фотосинтезу рослин та врожайність ячменю озимого (H. vulgare L.) за різних строків сівби в умовах зрошення півдня України.

\footnotetext{
${ }^{6}$ Анішин Л.А. Регулятори росту рослин: сумніви і факти. Пропозиція. 2002. № 5. С. 64-65.

${ }^{7}$ Біологічно активні речовини в рослинництві : навчальний посібник / 3.М. Грицаєнко та ін. Київ, 2008. $352 \mathrm{c}$

${ }^{8}$ Калитка В.В., Ялоха Т.М. Урожайність ячменю озимого за дії різних попередників та регулятора росту АКМ. Науковий віснник НУБІП. 2011. № 162. С. 89-93.

${ }^{9}$ Новікова Т.П. Фотосинтетична продуктивність посівів сочевиці за дії біологічних препаратів. Наукові горизонти. 2019. № 10(83). С. 28-34. DOI : 10.33249/2663-2144-2019-83-10-28-34.

${ }^{10}$ The influence of growth regulator and seeding rates on the formation of winter rape production in the conditions of the Western Forest-Steppe / M.I. Bakhmat et al. Agrology. 2019. № 2(3). P. 189-193. DOI : $10.32819 / 019027$

${ }^{11}$ Михайленко С.В. Технологія вирощування пивоварного ячменю з використанням регуляторів росту. Захист і карантин рослин. 2008. № 54. С. 299-305.

${ }_{12}^{12}$ Пономаренко С.П., Боровікова Г.С. Регулятори росту рослин. Захист рослин. 1997. № 11. С. 2-5.

${ }^{13}$ Перелік пестицидів та агрохімікатів дозволених до використання в Україні на 2016 рік. Київ : Юнівест Медіа. 2016. 1024 с.

${ }_{14}$ Білітюк А.П., Скуратівська О.В. Біостимулятори і урожайність. Захист рослин. 2000. № 10. C. 21.
} 


\section{1. Матеріали і методи дослідження та агромеотеорологічні умови у 2016, 2017, 2018 і 2019 роках}

Дослідження проводилися на зрошуваних землях в 2016-2019 pp. за методикою польових і лабораторних досліджень Інституту зрошуваного землеробства (I33) $\mathrm{HAAH}^{15}$. Грунт дослідного поля темно-каштановий, середньосуглинковий, слабкосолонцюватий з умістом гумусу - 2,3\%, щільністю - 1,37 г $/ \mathrm{cm}^{3}$, вологістю в'янення - 9,1\%, найменшою вологоємністю - 20,3\%.

У роки досліджень перед сівбою в орному шарі містилося: нітратів 7,9-24,2 мг, $\mathrm{P}_{2} \mathrm{O}_{5}-53,8-83,9, \mathrm{~K}_{2} \mathrm{O}-231-281$ мг на 1 кг грунту. Аміачна селітра вносилася під передпосівну культивацію в дозі $\mathrm{N}_{45}$ та рано навесні у підживлення $\mathrm{N}_{45}$. Насіння протруювали препаратом «Іншур Перформ» із розрахунку 0,5 л на 1 т зерна. Поливами вологість грунту на посівах підтримувалася на рівні $70 \%$ НВ у шарі 0-50 см. Висівалися сучасні сорти ячменю (H. vulgare L.): типово озимий Академічний i дворучка Дев'ятий вал, які занесені до Державного реєстру сортів рослин, придатних для поширення в Україні, відповідно з 2011 і 2014 pp. Попередником була соя (Glycine max L.), зібрана на зерно. Повторність триразова. Посівна площа ділянки $-25,0 \mathrm{~m}^{2}$, облікова $-20,6 \mathrm{~m}^{2}$.

За сівби ячменю озимого 1 i 20 жовтня та обробки насіння $\mathrm{i}$ обприскування у фазу кінця кущіння посівів регуляторами росту рослин Гуміфілд Форте брікс, MИP i PROLIS за допомогою акумуляторного ранцевого обприскувача FORTE CL-16A. Гуміфілд Форте брікс містить 60 г/л екстракту морських водоростей та 135 г/л солей гумінових кислот, у т. ч. амінокислот -20 г/л, калію $\left(\mathrm{K}_{2} \mathrm{O}\right)-20$ г/л і мікроелементів - 5 г/л. Доза його за обробки насіння 0,8 л/т, а за обприскування посіву $0,4 \pi / г^{16}$.

МИР - багатоцільовий імунорегулятор росту, створений на основі синтетичних сполук і має у собі широкий спектр мікроелементів у хелатній формі. Доза внесення під час обробки насіння - 6 г/т, а по вегетації- 6 г/га ${ }^{17}$.

PROLIS - L- $\alpha$ пролін амінокислота. PROLIS призначений для біотичного та абіотичного зменшення стресу рослин. Доза внесення під час обробки насіння -5 г/т, а по вегетації -2 г/га ${ }^{18}$.

Збирання й облік урожаю здійснювали прямим комбайнуванням, використовуючи комбайн Sampo - 130. Дані врожаю зерна приводилися

\footnotetext{
15 Методика польових і лабораторних досліджень на зрошуваних землях : науково-методичне видання / за ред. Р.А. Вожегової. Херсон : Грінь Д.С., 2014. 286 с.

${ }^{16}$ Гуміфілд, Гуміфілд Форте, Фульвітал Плюс. Рекламний проспект / Агротехносоюз. Київ, 2015. 32 с.

${ }^{17}$ Регулятор росту рослин МИР МАРКИ 3. IAC Аграрії разом. URL : https://agrarii-razom.com.ua/ preparations/mir-marki-z.

${ }_{18}$ Регулятор росту рослин PROLIS TM, В. IAC Аграрії разом. URL : https://agrarii-razom.com.ua/ preparations/prolis-tm-vp.
} 
до стандартної вологості та 100\% чистоти і піддавалися математичній обробці 3 використанням Microsoft Office Excel 2010 програми Agrostat $^{19}$.

Площу листкового апарату рослин ячменю озимого визначали методом «висічок» в основні фази росту та розвитку рослин: кущення, трубкування і колосіння.

Фотосинтетичний потенціал (ФП) та чисту продуктивність фотосинтезу (ЧПФ) розраховували за методикою О.О. Ничипоровича ${ }^{20}$ :

$$
\Phi \Pi=\frac{\left(J_{1}+J_{2}\right) t_{1}+\left(J_{2}+J_{3}\right) t_{2}+\ldots+\left(J_{n-1}+J_{n}\right) t_{n}}{2}, \mathrm{~m}^{2} \times \text { діб/га, }
$$

де $J_{1}, J_{2}, J_{3}, \ldots J_{n}$ - площа листків у відповідні строки визначення, м ${ }^{2}$; $t_{1}, t_{2}, t_{3} \ldots t_{n-1}$ - інтервали між строками обліку листкової поверхні; $n-$ кількість визначень.

$$
\text { ЧПФ= } \mathrm{B}_{2}-\mathrm{B}_{1} / 0,5 \times\left(\Omega_{1}+Л_{2}\right) \times t,
$$

де $B_{1}, B_{2}$ - суха маса рослин на початку і в кінці облікового періоду, г; $J_{1}, J_{2}-$ площа листків на початку і в кінці облікового періоду, м²; $t$ - період між двома обліками, діб.

Агрометеорологічні умови у роки проведення досліджень різнилися між собою. Осінній період 2016 р. був вологим та 3 температурою, близькою до норми. Тоді як у 2017 і 2018 рр. починаючи з другої половини літа і до середини жовтня на Півдні України утримувалася повітряна і грунтова посуха, що потребувало проведення вологозарядкових (400-500 м³/га) та сходовикликаючого (250 м³/га) поливів.

Умови весняно-літнього періоду за роками досліджень також різнилися: середньосухими вони були у 2017 і 2018 рр., а вологими - у 2019 р. Тому у 2017 і 2018 рр. на посівах ячменю озимого потребувалося проведення двох і трьох вегетаційних поливів зрошувальною нормою 800 і $1350 \mathrm{~m}^{3} /$ га відповідно, а в 2019 р. необхідність у таких поливах відпала. Такі неоднакові погодні умови в роки проведення досліджень по-різному впливали на фотосинтетичну продуктивність ячменю озимого.

\section{2. Площа листкової поверхні рослин та фотосинтетичний потенціал сортів ячменю озимого (H. vulgare L.) за різних строків сівби і регуляторів росту}

За даними Н.Д. Резніченко ${ }^{21}$, в умовах зрошення Півдня України оптимальна площа листкової поверхні ячменю озимого (H. vulgare L.)

\footnotetext{
${ }^{19}$ Статистичний аналіз результатів польових дослідів у землеробстві. / В.О. Ушкаренко та ін. Херсон : Айлант, 2013. 403 с.

20 Ничипорович А.А. Пути управления фотосинтетической деятельностью растений с целью повышения их продуктивности. Физиология с.-х. растений. Москва : МГУ, 1967. Т. 1. С. 309-353. 
сортів Достойний i Зимовий досягала свого максимуму в період колосіння та становила 58 і 60 тис $\mathrm{m}^{2} /$ га, що забезпечувало найвищу врожайність зерна - 6,35 і 6,14 т/га відповідно.

Нашими дослідженнями також установлено, що свого максимуму як за сівби 1 жовтня, так і 20 жовтня площа листкової поверхні рослин досягала у фазу «колосіння», і в 2017 р. вона відповідно становила $51,2-51,4$ і 45,5-49,8 тис м $^{2} /$ га на контрольних варіантах та 59,4-64,8 і $51,0-60,2$ тис $\mathrm{m}^{2} /$ га за застосування регуляторів росту. У 2018 р. ці показники були вищими і відповідно становили 57,7-58,5 i

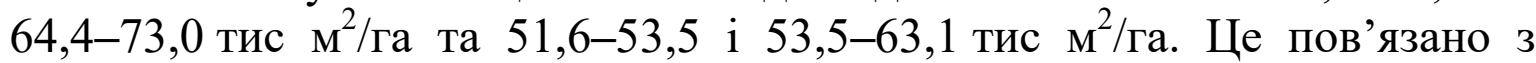
проведенням трьох вегетаційних поливів загальною нормою $1350 \mathrm{~m}^{3} /$ га, що сприяло кращому вологозабезпеченню рослин, аніж в інші роки.

Формування найменшої площі листя відзначено у 2019 р., коли вегетаційні поливи не проводилися, $-43,0-58,0$ і 41,7-50,3 тис м²/га та 43,2-61,7 і 43,6-60,2 тис м²/га відповідно. Особливо це проявилося на сорті Академічний за сівби у перший строк, що пов'язано з ранішим проходженням фаз розвитку на ньому, ніж за сівби у пізніший строк, та на сорті Дев'ятий вал. А значить, що він раніше розпочав утрачати листя.

Тобто простежуються сортові особливості формування і тривалості функціонування листкового апарату. Сорт Дев'ятий вал у середньому за три роки досліджень формував площу листя на 5,5 тис м²/га більшу, ніж сорт Академічний, що пов'язано з його біологічними властивостями як сорта-дворучки. Сорт Дев'ятий вал максимальну площу листкової поверхні 66,5 тис м²/га формував за сівби 1 жовтня й обробки насіння препаратом МИР, а сорт Академічний за цього ж строку сівби та обробки насіння препаратом Гуміфілд - 60,3 тис м²/га (рис. 1).

За сівби 20 жовтня сорт Дев'ятий вал також формував більшу площу листя $\left(60,1\right.$ тис $\mathrm{m}^{2} /$ га) за обробки насіння препаратом МИР, а сорт Академічний $(55,4$ тис м²/га) - за обробки рослин препаратом PROLIS.

Отже, на сортах ячменю озимого (H. vulgare L.) спостерігалася позитивна зміна величини листкової поверхні на користь обробки насіння та рослин регуляторами росту.

Установлено також, що сорти, строки сівби та регулятори росту впливають на величину фотосинтетичного потенціалу посіву (ФП), який характеризує роботу листової поверхні рослин ячменю озимого (H. vulgare L.) протягом вегетації.

Так, в умовах 2017, 2018 і 2019 pр. застосування регуляторів росту на сорті Академічний за сівби 1 жовтня сприяло збільшенню показників фотосинтетичного потенціалу відповідно на $0,20-0,26,0,24-0,39$ i

21 Резніченко Н.Д. Формування площі листкової поверхні рослинами ячменю озимого (Hordeum vulgare L.) за різних технологічних прийомів вирощування. Зрошуване землеробство : міжвід. темат. наук. зб. Херсон : ОЛДІ-ПЛЮС, 2017. Вип. 68. С. 123-126. 
0,15-0,21 млн м²/днів/га порівняно з контрольними варіантами $(1,61,1,45$ і 1,42 млн м²/днів/га), а на сорті Дев'ятий вал - на 0,20-0,32, 0,23-0,38 і 0,06-0,31 млн м²/днів/га (контроль - 1,62, 1,51 і 1,67 млн м²/днів/га) (табл. 1).

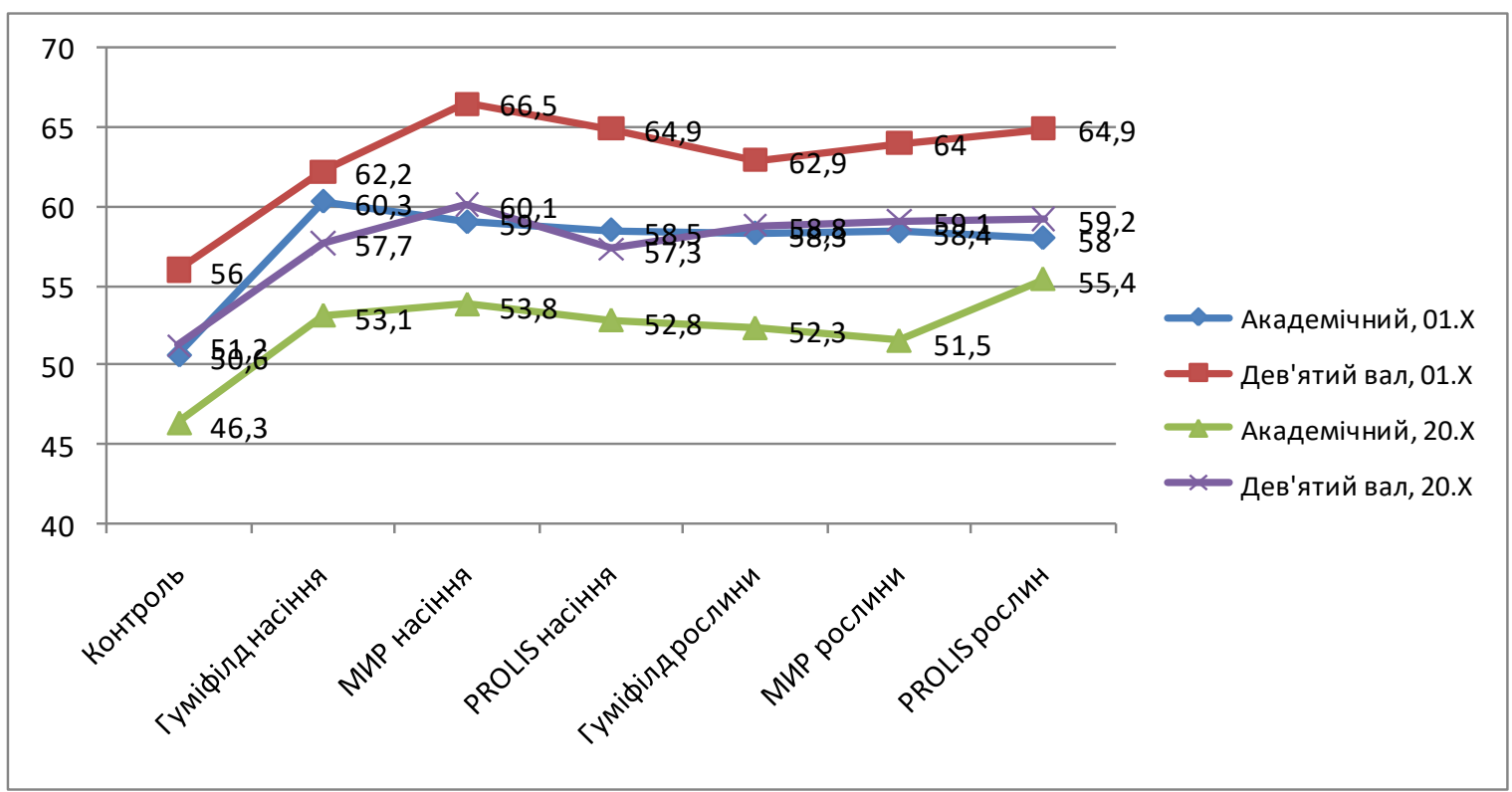

\section{Рис. 1. Площа листя рослин сортів Академічний і Дев'ятий вал за різних строків сівби і регуляторів росту (середня за 2017-2019 рр.)}

За сівби 20 жовтня цей показник на сортах Академічний і Дев'ятий вал також був більшим за застосування регуляторів росту: у 2017 р. - на 0,15-0,30 млн м²/днів/га і $0,07-0,25$ млн м²/днів/га; у 2018 p. - на $0,15-0,27$ млн м²/днів/га і $0,17-0,26$ млн м²/днів/га та в 2019 р. - на 0,05-0,31 млн м²/днів/га і $0,23-0,38$ млн м²/днів/га відповідно. На контрольних варіантах у ці роки фотосинтетичний потенціал сорту Академічний становив 1,35, 1,33 і 1,31 млн м²/днів/га, а Дев'ятого валу $1,55,1,27$ і 1,35 млн м²/днів/га. У всі роки досліджень максимальна величина фотосинтетичного потенціалу на обох сортах була отримана за сівби 1 жовтня, тільки у 2017 р. за обробки насіння і рослин препаратом PROLIS, у 2018 р. - за обприскування рослин, а в 2019 р. - за обробки насіння регулятором росту Гуміфілд.

I в середньому за три роки досліджень кращі показники фотосинтетичного потенціалу посіву обидва сорти забезпечували за сівби 1 жовтня і застосуванні регуляторів росту. Так, за цього строку сівби і без регуляторів росту фотосинтетичний потенціал за період «кущіння - колосіння» на сорті Дев'ятий вал становив 1,60 млн м²/днів/га, а з регуляторами росту - 1,81-1,88 млн м²/днів/га, або на $0,21-0,28$ млн м²/днів/га більше. За сівби 20 жовтня 
фотосинтетичний потенціал цього сорту під впливом регуляторів росту збільшувався в середньому з 1,39 до $1,58-1,63$ млн м²/днів/га, або на $13,7-17,3 \%$. Найбільшим (1,88 млн м²/днів/га) ФП був за сівби 1 жовтня та обробки насіння препаратами Гуміфілд і МИР.

\section{Таблиця 1}

Фотосинтетичний потенціал посівів ячменю озимого (H. vulgare $\mathrm{L}$.) залежно від застосування регуляторів росту, млн м² за днів/га

\begin{tabular}{|c|c|c|c|c|c|c|c|c|}
\hline \multirow{3}{*}{$\begin{array}{c}\text { Варіант } \\
\text { (регулятори росту) }\end{array}$} & \multicolumn{2}{|c|}{2017 p. } & \multicolumn{2}{|c|}{2018 p. } & \multicolumn{2}{|c|}{2019 p. } & \multicolumn{2}{|c|}{ Середнє } \\
\hline & \multicolumn{8}{|c|}{ Строки сівби } \\
\hline & 01.X & $20 . X$ & 01.X & $20 . \mathrm{X}$ & 01.X & $20 . \mathrm{X}$ & 01.X & $20 . \mathrm{X}$ \\
\hline \multicolumn{9}{|c|}{ сорт Академічний } \\
\hline Контроль & 1,61 & 1,35 & 1,45 & 1,33 & 1,42 & 1,31 & 1,49 & 1,33 \\
\hline Гуміфілд насіння & 1,82 & 1,65 & 1,69 & 1,54 & 1,63 & 1,55 & 1,71 & 1,58 \\
\hline МИР насіння & 1,81 & 1,58 & 1,80 & 1,60 & 1,55 & 1,62 & 1,72 & 1,60 \\
\hline PROLIS насіння & 1,87 & 1,59 & 1,73 & 1,54 & 1,62 & 1,36 & 1,74 & 1,50 \\
\hline Гуміфілд рослини & 1,83 & 1,59 & 1,84 & 1,59 & 1,59 & 1,55 & 1,75 & 1,58 \\
\hline МИР рослини & 1,82 & 1,50 & 1,75 & 1,48 & 1,62 & 1,43 & 1,73 & 1,47 \\
\hline PROLIS рослини & 1,86 & 1,53 & 1,75 & 1,58 & 1,57 & 1,56 & 1,73 & 1,56 \\
\hline \multicolumn{9}{|c|}{ сорт Дев'ятий вал } \\
\hline Контроль & 1,62 & 1,55 & 1,51 & 1,27 & 1,67 & 1,35 & 1,60 & 1,39 \\
\hline Гуміфілд насіння & 1,82 & 1,75 & 1,83 & 1,45 & 1,98 & 1,58 & 1,88 & 1,59 \\
\hline МИР насіння & 1,88 & 1,80 & 1,82 & 1,44 & 1,95 & 1,66 & 1,88 & 1,63 \\
\hline PROLIS насіння & 1,84 & 1,70 & 1,85 & 1,53 & 1,76 & 1,65 & 1,82 & 1,63 \\
\hline Гуміфілд рослини & 1,82 & 1,62 & 1,89 & 1,46 & 1,73 & 1,73 & 1,81 & 1,60 \\
\hline МИР рослини & 1,85 & 1,66 & 1,86 & 1,47 & 1,89 & 1,62 & 1,87 & 1,58 \\
\hline PROLIS рослини & 1,94 & 1,70 & 1,74 & 1,52 & 1,91 & 1,67 & 1,86 & 1,63 \\
\hline
\end{tabular}

Дещо менші показники, але 3 аналогічною закономірністю впливу регуляторів росту на фотосинтетичний потенціал, отримано на сорті Академічний, у якого ФП збільшувався на $0,22-0,26$ млн м² за добу/га, або $14,8-17,4 \%$, за сівби 1 жовтня і на $0,14-0,27$ млн м² за добу/га, або $10,5-20,3 \%$, за сівби 20 жовтня. Але рослини цього сорту максимальний ФП мали за сівби 1 жовтня та обприскуванні посівів препаратом Гуміфілд - 1,75 млн м²/днів/га.

Простежуються також сортові особливості тривалості функціонування листкового апарату. У сорту Дев'ятий вал величина фотосинтетичного потенціалу була більшою, ніж у Академічного, що пояснюється більш тривалішою роботою його листкового апарату. У сорту Академічний 
листя в колосіння й пізніше відмирали швидше, ніж у Дев'ятого валу, особливо це проявилося в 2019 p.

\section{3. Чиста продуктивність фотосинтезу та врожайність сортів ячменю озимого (H. vulgare $L$.) за різних строків сівби і регуляторів росту}

Якісна робота листкового апарату рослин визначається чистою продуктивністю фотосинтезу (ЧПФ). Показник ЧПФ визначає кількість сухої біомаси рослин, що створюється в процесі фотосинтезу протягом доби з розрахунку на $1 \mathrm{~m}^{2}$ листя.

Установлено, що за період «кущіння - колосіння» кожен квадратний метр листкової поверхні ячменю озимого (H. vulgare L.) створює від 3,9 до 11,9 г сухої речовини за добу залежно від агрометеорологічних умов року, біологічних особливостей сорту, строку сівби та регуляторів росту (табл. 2).

Таблиця 2

Чиста продуктивність фотосинтезу посівів ячменю озимого (H. vulgare L.) залежно від застосування регуляторів росту, $г / \mathbf{M}^{2}$ за добу

\begin{tabular}{|c|c|c|c|c|c|c|c|c|}
\hline \multirow{3}{*}{$\begin{array}{c}\text { Варіант } \\
\text { (регулятори } \\
\text { росту) }\end{array}$} & \multicolumn{2}{|c|}{2017 p. } & \multicolumn{2}{|c|}{2018 p. } & \multicolumn{2}{|c|}{2019 p. } & \multicolumn{2}{|c|}{ Середнє } \\
\hline & \multicolumn{8}{|c|}{ Строки сівби } \\
\hline & 01.X & $20 . \mathrm{X}$ & 01.X & 20.X & 01.X & $20 . X$ & 01.X & $20 . X$ \\
\hline \multicolumn{9}{|c|}{ сорт Академічний } \\
\hline Контроль & 4,4 & 3,6 & 5,9 & 2,9 & 4,1 & 3,9 & 4,8 & 3,5 \\
\hline Гуміфілд насіння & 5,7 & 3,7 & 10,2 & 6,3 & 4,9 & 4,2 & 6,9 & 4,7 \\
\hline МИР насіння & 4,7 & 4,2 & 7,9 & 6,6 & 5,5 & 4,2 & 6,0 & 5,0 \\
\hline PROLIS насіння & 5,4 & 3,7 & 11,0 & 7,3 & 5,3 & 4,9 & 7,2 & 5,3 \\
\hline Гуміфілд рослини & 5,3 & 3,7 & 11,9 & 6,6 & 6,4 & 4,3 & 7,9 & 4,9 \\
\hline МИР рослини & 4,6 & 4,3 & 6,5 & 6,3 & 5,3 & 4,6 & 5,5 & 5,1 \\
\hline PROLIS рослини & 4,5 & 4,0 & 6,7 & 9,4 & 5,4 & 4,7 & 5,5 & 6,0 \\
\hline \multicolumn{9}{|c|}{ сорт Дев'ятий вал } \\
\hline Контроль & 3,4 & 3,0 & 7,2 & 6,3 & 6,1 & 4,1 & 5,6 & 4,5 \\
\hline Гуміфілд насіння & 4,0 & 3,4 & 11,7 & 7,5 & 6,4 & 4,4 & 7,4 & 5,1 \\
\hline МИР насіння & 3,6 & 3,1 & 11,2 & 9,7 & 7,4 & 4,4 & 7,4 & 5,7 \\
\hline PROLIS насіння & 3,7 & 3,5 & 8,8 & 7,4 & 7,5 & 5,0 & 6,7 & 5,3 \\
\hline Гуміфілд рослини & 3,9 & 3,4 & 11,0 & 9,1 & 8,0 & 4,6 & 7,6 & 5,7 \\
\hline МИР рослини & 4,2 & 3,3 & 9,5 & 7,9 & 9,3 & 4,9 & 7,7 & 5,4 \\
\hline PROLIS рослини & 4,0 & 3,3 & 11,1 & 9,4 & 6,3 & 4,3 & 7,1 & 5,7 \\
\hline
\end{tabular}


Найефективнішою робота асиміляційного апарату ячменю озимого (H. vulgare L.) була у 2018 р. : показники чистою продуктивністю

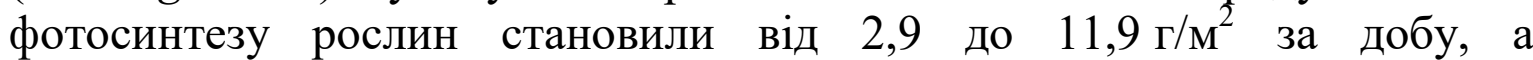

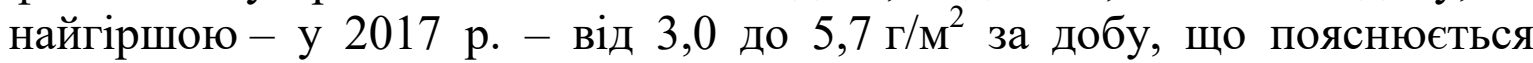
складними погодними умовами цього року. У 2019 р. показники ЧПФ становили від 3,9 до 9,3 г/м² за добу.

Слід відзначити, що у 2018 і 2019 рр. сорт Дев'ятий вал порівняно із сортом Академічний мав вищий рівень даного показника - відповідно на

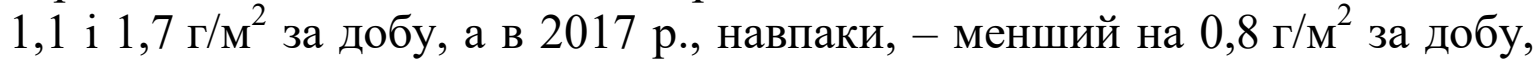
що пов'язано як зі складними погодними умовами 2016/2017 р., так і біологічними особливостями сортів (Академічний - типово зимовий сорт, а Дев'ятий вал - сорт-дворучка).

Установлено, що величина чистої продуктивності фотосинтезу рослин ячменю озимого залежала не лише від агрометеорологічних умов року, а й від сорту, строків сівби та регуляторів росту. Так, у 2017 р. ЧПФ рослин сорту Академічний за сівби 1 жовтня і 20 жовтня та з регуляторами росту

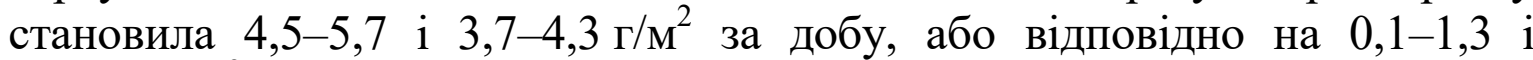
$0,1-0,7 \Gamma / \mathrm{M}^{2}$ за добу більше, ніж без них. На сорті Дев'ятий вал ЧПФ рослин за цих строків сівби і з регуляторами росту була дещо меншою,

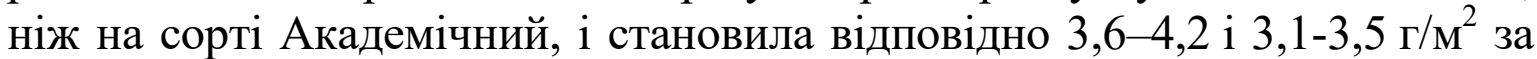

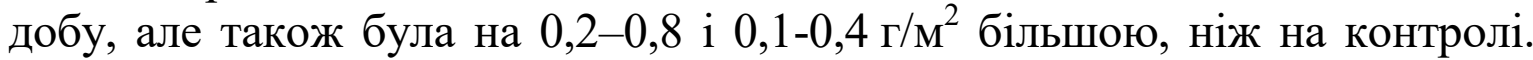
Найкращі результати ЧПФ рослини сорту Академічний забезпечували за сівби 1 жовтня та обробки насіння препаратом Гуміфілд Форте брікс $5,7 \Gamma / \mathrm{M}^{2}$ за добу, а сорту Дев'ятий вал - за цього строку сівби й обробки рослин препаратом МИР $-4,2$ г/м ${ }^{2}$ за добу.

У 2018 р. на контрольному варіанті ЧПФ рослин сорту Академічний за сівби 1 жовтня становила $5,9 \Gamma / \mathrm{M}^{2}$ за добу, а за застосування

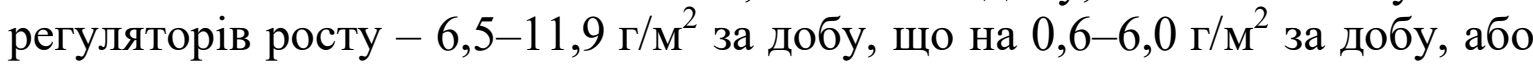
на $10-102 \%$, більше. Чиста продуктивність фотосинтезу рослин сорту

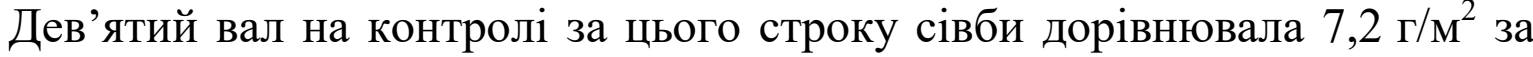
добу, а за застосування регуляторів росту вона збільшилася на $1,6-4,5$ г/м² за добу, або на 22-63\%. Найкращі результати на обох сортах забезпечував препарат Гуміфілд - 11,7 і 11,9 г/м² за добу.

Дещо менший показник ЧПФ отримано на посівах обох сортів ячменю озимого (H. vulgare L.) за сівби 20 жовтня. Це можна пояснити тим, що за пізнішого терміну сівби прискорюється проходження фаз розвитку та погіршуються ростові процеси. На сорті Академічний кращі результати одержані за обприскування рослин препаратом PROLIS 9,4 г/M за добу, а на сорті Дев'ятий вал - за обробки насіння препаратом МИР та рослин препаратом PROLIS $-9,4$ г/м² за добу.

Найгірші показники на обох сортах ячменю озимого (H. vulgare L.), як за першого, так і за другого строку сівби, були отримані на контрольних варіантах без обробки регуляторами росту $-2,9-7,2$ г/м² за добу. 
У 2019 р. сорт Дев'ятий вал мав перевагу над Академічним щодо даного показника. Така тенденція спостерігалася майже на всіх варіантах досліду. Величина ЧПФ у сорту Дев'ятий вал за сівби

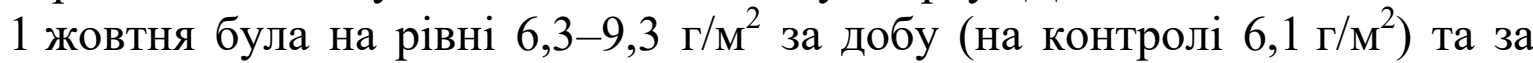

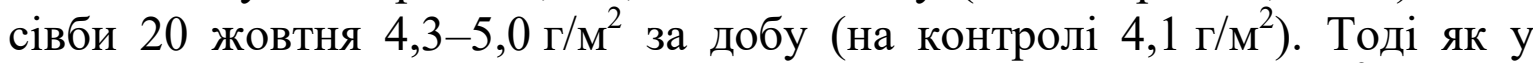
сорту Академічний за сівби 1 жовтня вона становила 4,9-6,4 г/м² за добу

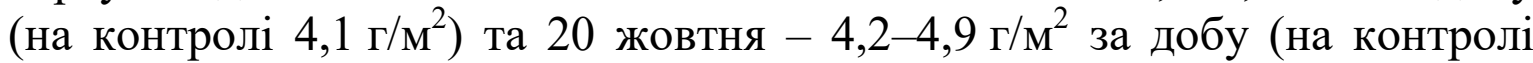
$\left.3,9 \Gamma / \mathrm{M}^{2}\right)$. Це зумовлено біологічними особливостями сортів та погоднокліматичними умовами $2019 \mathrm{p}$.

У середньому за три роки досліджень ЧПФ у рослинах ячменю озимого (H. vulgare L.) залежала як від строків сівби, так і застосування регуляторів росту. Так, за сівби 1 жовтня чиста продуктивність фотосинтезу сорту Академічний на контрольному варіанті становила 4,8 г/M $\mathbf{M}^{2}$ за добу. Передпосівна обробка насіння регуляторами росту

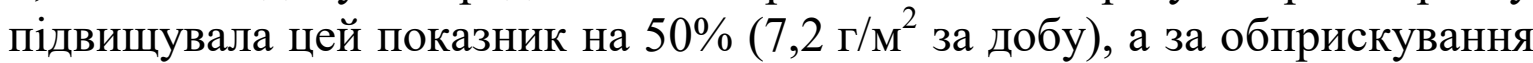
рослин - на $65 \%$ (7,9 г/м ${ }^{2}$ за добу). За сівби 20 жовтня на контрольному варіанті ЧПФ становила 3,5 г/м² за добу, а передпосівна обробка насіння й обприскування рослин регуляторами росту підвищували іiі величину на

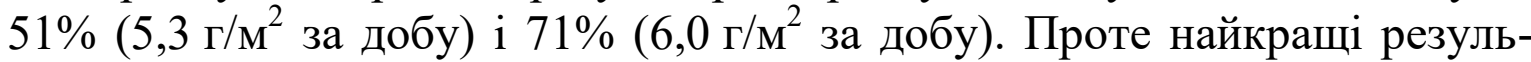
тати ЧПФ сорт Академічний забезпечував за обприскування рослин препаратом Гуміфілд та сівби 1 жовтня.

На сорті ячменю озимого (H. vulgare L.) Дев'ятий вал спостерігалася аналогічна тенденція щодо зміни ЧПФ за застосування регуляторів

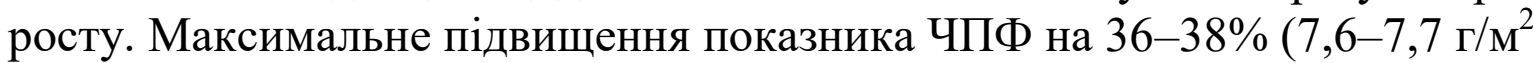
за добу) у сорту Дев'ятий вал відбувалося за сівби 1 жовтня та обприскуванні рослин препаратами Гуміфілд і МИР.

За другого строку сівби (20 жовтня) значення цього показника було

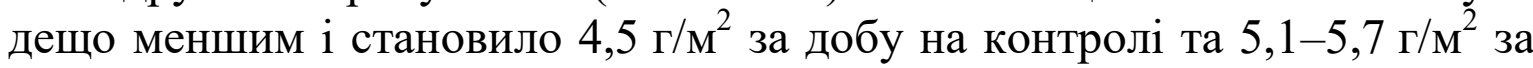
добу за застосування регуляторів росту. У цей строк сівби найбільше зростання ЧПФ на 27\% забезпечували обробка насіння препаратом МИР та обприскування рослин препаратами Гуміфілд і PROLIS.

Отже, чиста продуктивність фотосинтезу рослин обох сортів ячменю озимого (H. vulgare L.) значно зростає за застосування регуляторів росту, як за обробки насіння, так і обприскування посівів.

Урожайність $є$ основним показником, що визначає вплив агрометеорологічних і технологічних чинників. Установлено достовірний зв'язок між чистою продуктивністю фотосинтезу та врожайністю ячменю озимого (H. vulgare L.), який суттєво залежав від сорту, строків сівби і регуляторів росту. У сорту Академічний коефіцієнт кореляції між ЧПФ і врожайністю за сівби 1 жовтня становив 0,75 , а за сівби 20 жовтня - 0,72 (рис. 2). 


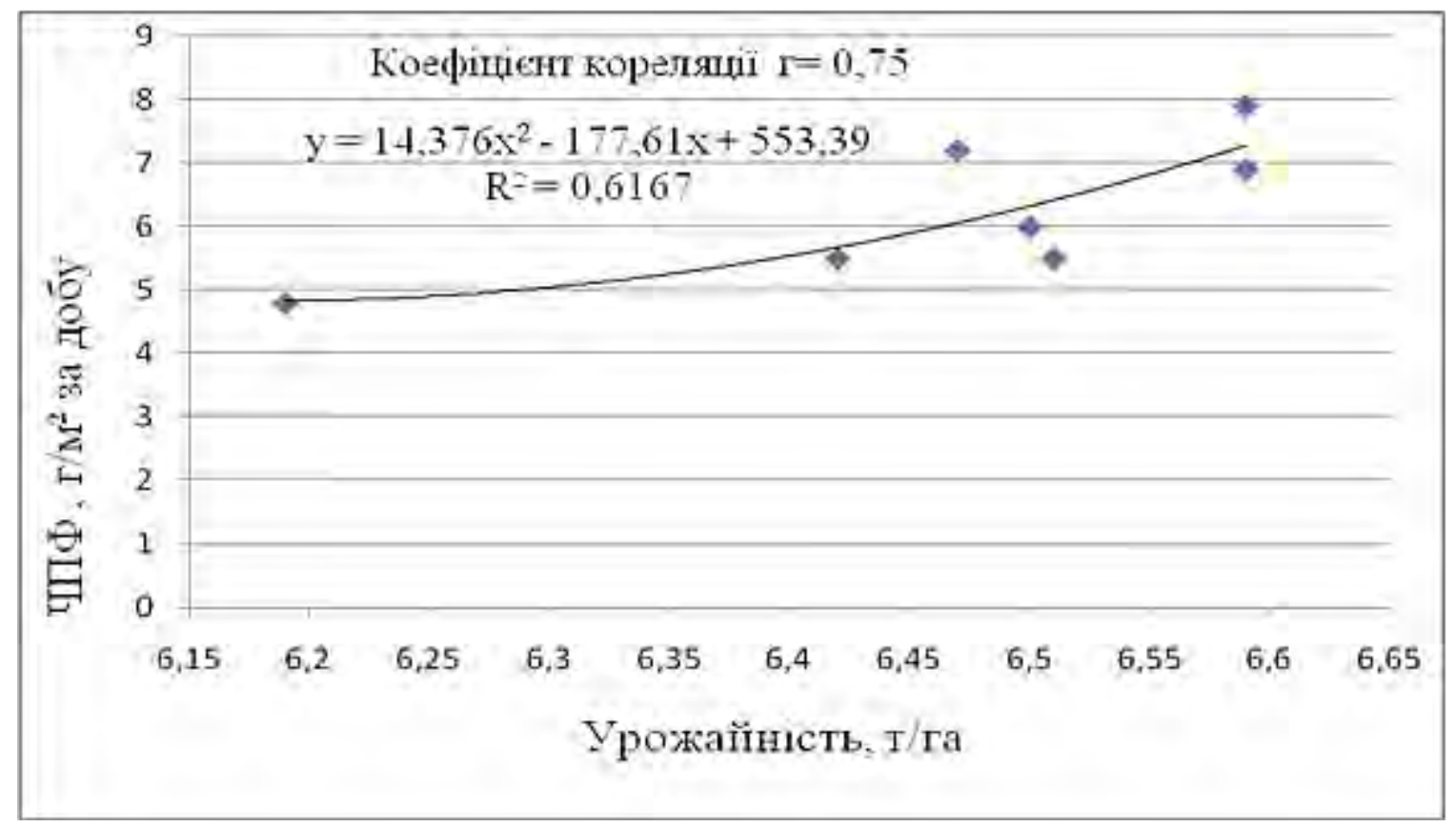

Рис. 2. Коефіціснт кореляції та поліноміальна лінія тренда зв'язку між чистою продуктивністю фотосинтезу та врожайністю сорту Академічний за сівби 1 жовтня

У сорту Дев'ятий вал зв'язки ЧПФ з урожайністю були не такими високими і становили 0,67 за сівби 1 жовтня і 0,56-20 жовтня (рис. 3).

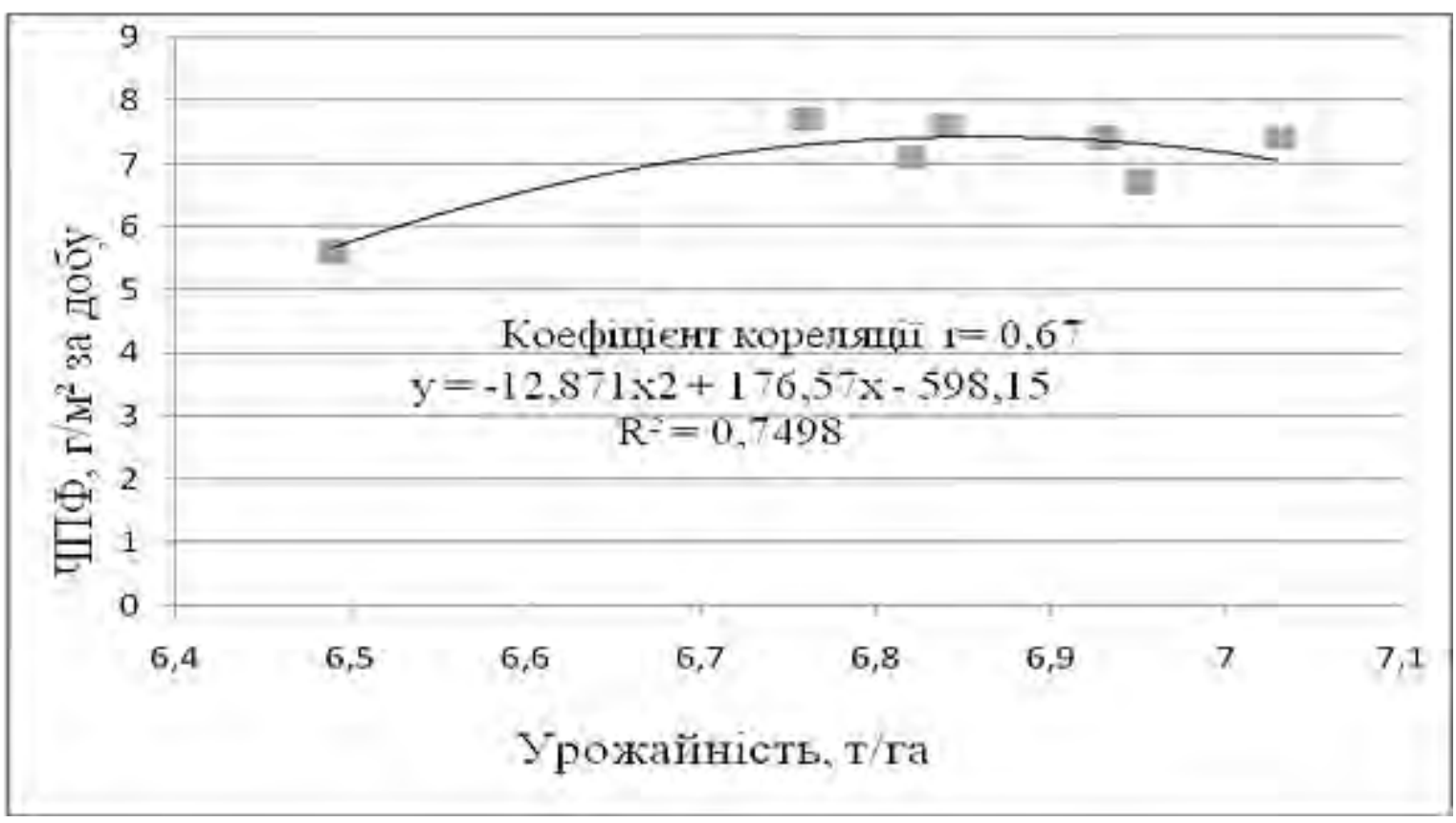

Рис. 3. Коефіціснт кореляції та поліноміальна лінія тренда зв'язку між чистою продуктивністю фотосинтезу та врожайністю сорту Дев'ятий вал за сівби 1 жовтня 
За сівби 1 жовтня ячмінь озимий (H. vulgare L.) обох сортів без застосування регуляторів росту забезпечив найнижчу врожайність, середнє значення якої за 2017-2019 рр. досліджень становило на сорті Академічний 6,19 т/га і на сорті Дев'ятий вал - 6,49 т/га (рис. 4, 5). Передпосівна обробка насіння ячменю озимого та обробка рослин по вегетації регуляторами росту підвищує врожайність зерна сортів Академічний і Дев'ятий вал порівняно з контролем за сівби 1 жовтня на 3,7-6,5 і 4,2-8,3\% та 20 жовтня - на 5,5-8,4 і 4,6-9,0\% відповідно.

Слід відзначити, що діапазони варіювання врожайності ячменю озимого (H. vulgare L.) сорту Академічний більшими були за сівби 1 жовтня і незначними - 20 жовтня. Тоді як у сорта-дворучки Дев'ятий вал діапазони варіювання врожайності за першого і другого строків сівби були близькими, що пояснюється його біологічними особливостями. Проте вищу врожайність зерна обидва сорти формували за сівби 1 жовтня.

Використання регуляторів росту сприяло підвищенню врожайності на обох сортах ячменю озимого (H. vulgare L.).

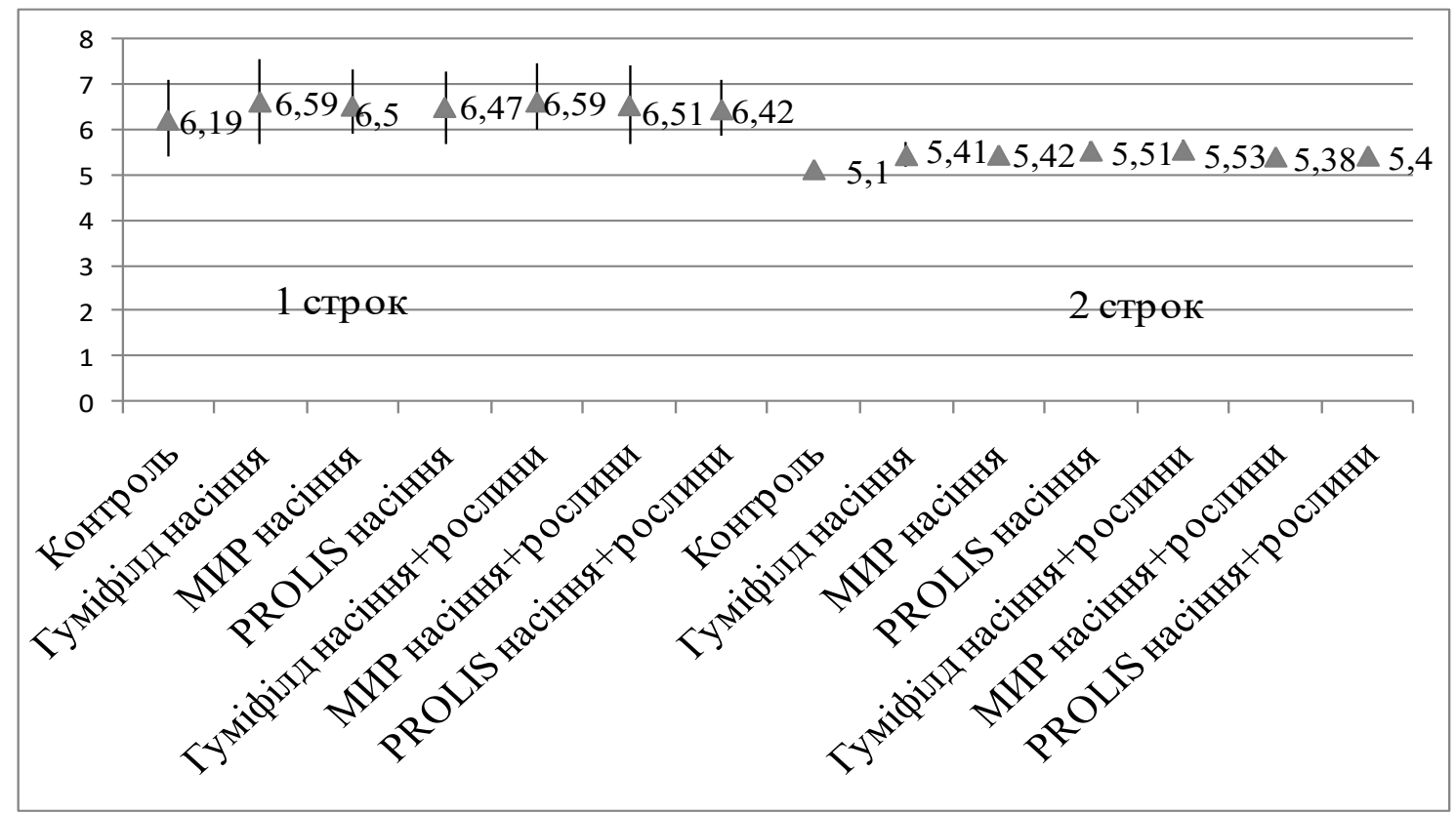

Рис. 4. Діапазон варіювання врожайності сорту Академічний залежно від регуляторів росту і строку сівби за 2017-2019 рр., т/га

За роки досліджень середній приріст урожайності сорту Академічний за сівби 1 жовтня та використання регуляторів росту становив $0,32 \mathrm{~T} / г$, або 5,2\%, і 20 жовтня - 0,34 т/га, або 6,7\%, а сорту Дев'ятий вал 0,40 т/га, або 6,2\%, і 0,39 т/га, або 6,6\%, відповідно. 


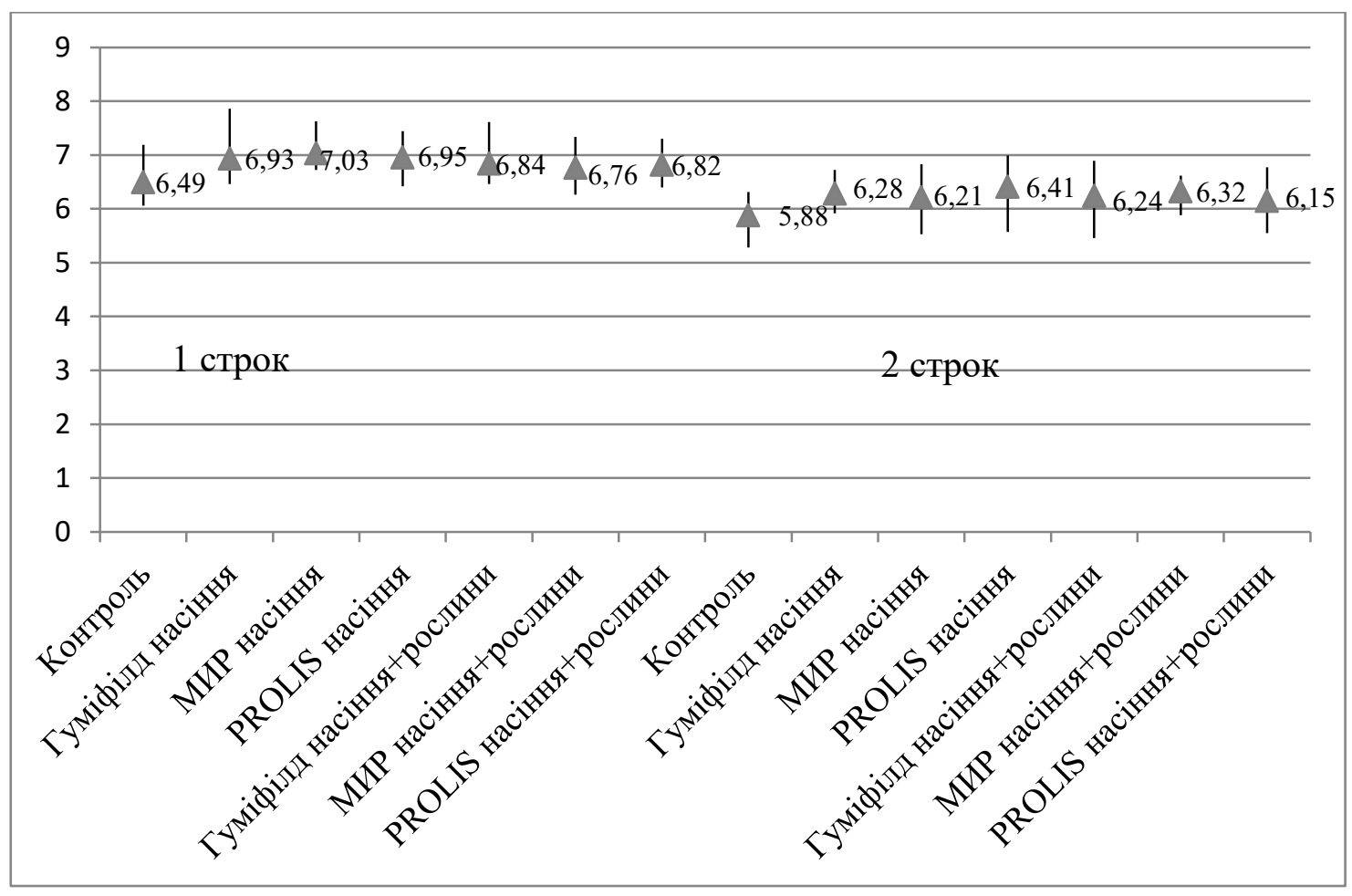

Рис. 5. Діапазон варіювання врожайності сорту Дев'ятий вал залежно від регуляторів росту і строку сівби за 2017-2019 рр., т/га

Максимальну врожайність (7,03 т/га) сорт Дев'ятий вал за сівби 1 жовтня формував за обробки насіння препаратом МИР, а за сівби 20 жовтня препаратом PROLIS - 6,41 т/га. На сорті Академічний за обох строків сівби кращу врожайність забезпечував препарат Гуміфілд, як за обробки насіння, так і посіву - 6,59 т/га та 5,53 т/га відповідно.

\section{ВИСНОВКИ}

Застосування регуляторів росту позитивно впливає на фотосинтетичну діяльність рослин нових сортів ячменю озимого (H. vulgare L.). У рослин збільшуються площа листкової поверхні, фотосинтетичний потенціал, чиста продуктивність фотосинтезу та, відповідно, врожайність. У середньому за 2017-2019 рр. використання регуляторів росту рослин на сортах Академічний і Дев'ятий вал за сівби 1 і 20 жовтня збільшувало фотосинтетичний потенціал (ФП) відповідно на 0,22-0,26 i 0,14 0,27 млн м²/днів/га та $0,21-0,28$ і $0,19-0,24$ млн м²/днів/га, а чисту продуктивність фотосинтезу (ЧПФ) на $0,7-3,1$ г/ $\mathrm{m}^{2}$ і $1,2-2,5$ та $1,1-2,1$ i $0,6-1,2$ г/м² за добу.

Установлено достовірний зв'язок між чистою продуктивністю фотосинтезу та врожайністю ячменю озимого (H. vulgare L.), який суттєво залежав від сорту, строків сівби і регуляторів росту $(\mathrm{r}=0,56-0,75)$.

У середньому за роки досліджень найвища врожайність $(7,03$ т/га) була отримана на сорті Дев'ятий вал за сівби 1 жовтня й обробки 
насіння препаратом МИР, а на сорті Академічний 6,59 т/га - за цього строку сівби і обробки насіння та посівів препаратом Гуміфілд Форте брікс.

\section{АНОТАЦІЯ}

У статті представлено результати польових досліджень щодо встановлення впливу біологічних регуляторів росту і строків сівби на формування площі листкової поверхні, фотосинтетичного потенціалу, чистої продуктивності фотосинтезу та врожайності різних сортів ячменю озимого (Hordeum vulgare L.) в умовах зрошення. Дослідження проводилися на сортах ячменю типово озимому Академічний і дворучки Дев'ятий вал за сівби 1 і 20 жовтня та обробки насіння і рослин регуляторами росту Гуміфілд Форте брікс, MИP і PROLIS. Встановлено, що на сортах ячменю озимого (H. vulgare L.) спостерігалася позитивна зміна величини листкової поверхні на користь обробки насіння та рослин регуляторами росту. Сорт Дев'ятий вал максимальну площу листкової поверхні 66,5 тис м²/га формував за сівби 1 жовтня й обробки насіння препаратом МИР, а сорт Академічний за цього ж строку сівби та обробки насіння препаратом Гуміфілд - 60,3 тис м²/га. Використання регуляторів росту рослин на сортах Академічний і Дев'ятий вал за сівби 1 і 20 жовтня збільшувало фотосинтетичний потенціал (ФП) відповідно на 0,22-0,26 і $0,14-0,27$ млн м ${ }^{2} /$ днів/га та $0,21-0,28$ і $0,19-0,24$ млн м²/днів/га, а чисту продуктивність фотосинтезу (ЧПФ) - на $0,7-3,1$ г/м ${ }^{2}$ i $1,2-2,5$ та $1,1-2,1$ i $0,6-1,2 \Gamma / \mathrm{M}^{2}$ за добу. Виявлено достовірний зв'язок між чистою продуктивністю фотосинтезу та врожайністю ячменю озимого (H. vulgare L.), який суттєво залежав від сорту, строків сівби і регуляторів росту і становив $r=0.56-0.75$. Максимальну врожайність $(7,03$ т/га) сорт Дев'ятий вал за сівби 1 жовтня формував за обробки насіння препаратом МИР, а за сівби 20 жовтня препаратом PROLIS - 6,41 т/га. На сорті Академічний за обох строків сівби кращу врожайність забезпечував препарат Гуміфілд, як за обробки насіння, так і посіву 6,59 т/га та 5,53 т/га відповідно.

\section{ЛІТЕРАТУРА}

1. Системи землеробства на зрошуваних землях України / Р.А. Вожегова та ін. Київ : Аграрна наука, 2014. 360 с.

2. Ничипорович А.А. Некоторые принципы комплексной оптимизации фотосинтетической деятельности и продуктивность растений. Важнейшие проблемы фотосинтеза в растениеводстве. Москва : АН CCCP, 1970. С. 6-22.

3. Чириков Ю.Г. Фотосинтез: два века спустя. Москва : Знание, 1981. $192 \mathrm{c}$. 
4. Заєць С.О., Онуфран Л.І. Ячмінь ярий на півдні України : монографія. Херсон : ОЛДІ-ПЛЮС, 2019. 164 с.

5. Нетіс I.T. Пшениця озима на Півдні України : монографія. Херсон : ОЛДІ-ПЛЮС, 2011. 460 с.

6. Анішин Л.А. Регулятори росту рослин: сумніви i факти. Пропозииія. 2002. № 5. С. 64-65.

7. Біологічно активні речовини в рослинництві : навчальний посібник / 3.М. Грицаєнко та ін. Київ, 2008. 352 с.

8. Калитка В.В., Ялоха Т.М. Урожайність ячменю озимого за дії різних попередників та регулятора росту АКМ. Науковий вісник НУБІП. 2011. № 162. C. 89-93.

9. Новікова Т.П. Фотосинтетична продуктивність посівів сочевиці за дії біологічних препаратів. Наукові горизонти. 2019. № 10(83). С. 28-34. DOI : $10.33249 / 2663-2144-2019-83-10-28-34$.

10. The influence of growth regulator and seeding rates on the formation of winter rape production in the conditions of the Western Forest-Steppe / M.I. Bakhmat et al. Agrology. 2019. № 2(3). P. 189-193. DOI : 10.32819/ 019027.

11. Михайленко С.В. Технологія вирощування пивоварного ячменю 3 використанням регуляторів росту. Захист і карантин рослин. 2008. № 54. C. 299-305.

12. Пономаренко С.П., Боровікова Г.С. Регулятори росту рослин. Захист рослин. 1997. № 11. С. 2-5.

13. Перелік пестицидів та агрохімікатів, дозволених до використання в Україні на 2016 рік. Київ : Юнівест Медіа. 2016. 1024 с.

14. Білітюк А.П., Скуратівська О.В. Біостимулятори і урожайність. Захист рослин. 2000. № 10. С. 21.

15. Методика польових і лабораторних досліджень на зрошуваних землях : науково-методичне видання / за ред. Р.А. Вожегової. Херсон : Грінь Д.С., 2014. 286 с.

16. Гуміфільд та Гуміфільд вр-18. Рекламний проспект. Агротехносоюз. Київ, 2013. 18 с.

17. Регулятор росту рослин МИР МАРКИ 3. ІАС Аграрії разом. URL : https://agrarii-razom.com.ua/preparations/mir-marki-z.

18. Регулятор росту рослин PROLIS TM, B. IAC Аграрії разом. URL : https://agrarii-razom.com.ua/preparations/prolis-tm-vp.

19. Статистичний аналіз результатів польових дослідів у землеробстві / В.О. Ушкаренко та ін. Херсон : Айлант, 2013. 403 с.

20. Ничипорович А.А. Пути управления фотосинтетической деятельностью растений с целью повышения их продуктивности. Физиология с.-х. растений. Москва : МГУ, 1967. Т. 1. С. 309-353. 
21. Резніченко Н.Д. Формування площі листкової поверхні рослинами ячменю озимого (Hordeum vulgare L.) за різних технологічних прийомів вирощування. Зрошуване землеробство : між від. темат. наук. зб. Херсон : ОЛДІ-ПЛЮС, 2017. Вип. 68. С. 123-126.

\section{Information about authors:} Zaiets S. O.,

Candidate of Agricultural Sciences, Senior Researcher, Head of the Department of Crop Production and Non-Irrigated Agriculture Institute of Irrigated Agriculture of the National Academy of Agrarian Sciences of Ukraine Naddnipryanske sett., Kherson, 73483, Ukraine

Kysil L. B., Graduate Student Institute of Irrigated Agriculture of the National Academy of Agrarian Sciences of Ukraine Naddnipryanske sett., Kherson, 73483, Ukraine 